\title{
A Review of Trends in Import of Some Selected Foods in Nigeria (1981-2010): Matters Arising
}

\author{
Olawamiwa Reuben Adeniyi*, Busola A. Adeyemo \\ Department of Agricultural Economics and Extension, Bowen University, Iwo, Nigeria \\ Email: ${ }^{*}$ adeniyiwamiwa2008@yahoo.com
}

Received 22 March 2014; revised 21 April 2014; accepted 14 May 2014

Copyright (C) 2014 by authors and Scientific Research Publishing Inc.

This work is licensed under the Creative Commons Attribution International License (CC BY).

http://creativecommons.org/licenses/by/4.0/

(c) (i) Open Access

\section{Abstract}

This research assessed empirically the quantitative analysis of some selected food imports of Nigeria (rice, wheat and sugar). Time series data were used to examine the determinant of total food imports and the trend in the quantity of the food imported. The secondary data were obtained from institutional and national database over 1981-2010. Descriptive statistics, regression and correlation analysis were used as analytical tools. Statistical analysis shows that food deficit began in the 1970's, when Nigeria started the importation of food to feed the country. The result of the correlation analysis shows that the postulated determinants of food imports were positively correlated with the quantity of food import. The test for the individual variables shows that; national income explains $40 \%$, external reserves explains $38 \%$, food production index explains $46 \%$, population explains $58 \%$ and exchange rate explains $\mathbf{7 4 \%}$ of the total variation in the quantity of food import. The over-all goodness of fit of the regression analysis result shows that, the postulated regressors namely, relative price, national income, external reserves, lagged index of domestic food production, population estimate and exchange rate explained approximately $70 \%$ of the variability in the quantity of the selected food imports for the period of study. Consequently, there is the need for Nigeria to shift base from the ideology of nationalist orientation, as well as afro centric point of view and move towards unrestrained export-led growth that seeks to develop that market as the first option with corresponding development in international trade. This is however possible by limiting the importation of foods/raw materials that can be sourced for locally, increasing the domestic production of food generally and maintaining a healthy foreign investment with developed countries as a short term measure while in the long run, diversification of the economy, massive investment in agriculture and introduction of population control measures could serve as saviours to lower the rate of increase in food import demand.

${ }^{*}$ Corresponding author. 


\section{Keywords}

Trends, Food Import, Increased Domestic Production, Export-Led Growth, Population Control

\section{Introduction}

\subsection{Agriculture in Nigeria's Economy}

Nigeria is one of the largest countries in Africa, with a total geographical area of 923,768 square kilometres and an estimated population of about 138 million in 2008 [1] with an average annual growth rate of more than $3.00 \%$ [2], implying an estimated population of about 170 million presently [3]. Nigeria has highly diversified agroecological conditions, which make possible, the production of a wide range of agricultural products. The Nigeria's economy is dominated by agriculture. Over $60 \%$ of the population are engaged in this sector with an average of $41 \%$ contribution to the GDP [4]. Agriculture therefore constitutes one of the most important sectors of the economy. The sector is particularly important in being a major source of raw materials, food and foreign exchange; employing over 70 percent of the Nigeria labour force and serving as a potential vehicle for diversifying the economy [5]. Nigeria at independence in 1960 was largely a producer and net exporter of primary products. The six major agriculture products were cocoa, rubber, palm oil, groundnut, cotton and palm kernel. In other words, agricultural produce and raw materials constituted the sole foreign exchange earner for the country. Specifically, the Nigerian state as an exporter of agricultural goods had $69.4 \%$ of its total GDP for the year 1963/1964 comprising the six aforementioned agricultural commodities [6].

\subsection{Food Importation in Nigeria}

The trend of having agriculture as the main foreign exchange earner for Nigeria stopped in the 1970's, when the country suddenly experienced a tremendous increase in the influx of petrol dollars arising from the quadruple increase in the price of oil in the world market. From 1972 onwards, oil gained ascendancy over all other commodities as the largest contributor to the GDP, and also as a major foreign exchange earner. The agricultural sector was negatively impacted as boom in the oil sector lured labour away from rural sectors to urban centres [7]. As such, production of agricultural products declined and the country started witnessing massive importation of food and other items into the country. Significantly, the country became a net importer of food. In view of the fact that no country can constitute itself an island, food importation becomes necessary among countries of the world in order to supplement the ones available in the country. Food importation was adopted in the country by the national government, but recommended only as a short-term measure because it drains the scarce foreign exchange earnings which are needed for the importation of capital goods necessary for economic development [8]. It is also important to note that, with such an unrestricted importation, there is the possibility of entry of unsecured food items which may be hazardous to the general health of the populace into the country. In this context, food importation may not at all times ensure food security in the country.

\subsection{Need for Agricultural Transformation}

The idea of importing food to meet the food shortage was later dropped because food import bills grew substantially and was taking a larger share of the Gross Domestic Product. Researchers have warned that apart from the fact that the terms of trade could be set against Nigeria as a food-importing nation, she would be exposing herself unwittingly to the misfortunes of food-exporting countries if she relied on the importation of food stuffs on a long-time basis [9]. They therefore went ahead to recommend that the only rational means of providing a long-term solution to the problems of food shortage in the country was speeding up the rate of domestic food production. Re-forming the agricultural sector is the only catalyst to increase domestic food production, since agriculture transformation is not all about food; it is about the economy [10] [11]. Agricultural development with a focus on self-sufficiency via import substitution lowers the cost of food, real wages and drives down inflation. It is a rapid transition to an export-oriented agricultural economy, diversifies the economy thereby increasing foreign exchange reserves and stabilizes the exchange rate. These coupled with reduced inflation, drive macro-economic stability which will in turn significantly increase the level of foreign direct investment. 
As a starting point, it would be fruitful examining the trends in the importation of food and the quantifiable factor-contributors to the rapid expansion in Nigeria's food imports over the past three decades. In this way, attention of economic planners may be drawn to the macro-economic variables, which can be manipulated to control the rate of unbridled food importation in Nigeria. This, as a great challenge, is hoped to provide the pedestal to spring-board agricultural transformation in the country.

\section{Materials and Methods}

\subsection{The Data}

The study used Macro level data from 1981 to 2010. The data were largely sourced from various publications/ issues of the Central Bank of Nigeria (CBN) statistical bulletin [12]-[16], Nigeria Bureau of Statistics and the Food and Agriculture Organization (FAO) of the United Nations [17]. The data were subjected to statistical analysis and presented in graphs and tables to show the trend in the quantity of food import; correlation and regression models were also used to show the relationship between the explanatory variables and the quantity of food import for the study period. The functional forms of the model namely; linear, semi-log and double-log were specified and evaluated and; on the basis of econometric and statistical criteria, the linear model that best describes the data was selected as the most appropriate one.

\subsection{The Model}

The model used for the analysis is implicitly specified as follows:

$$
Q F_{i t}=f\left(P R_{t}, N I_{t}, E R_{t-1}, F P_{t-1}, P L_{t}, X R_{t}, U_{t}\right)
$$

where:

$Q F_{i t}=$ Net import of food in year $\mathrm{t}$ in metric tones;

$P R_{t}=$ Relative price of the food grain in year $\mathrm{t}$; obtained when the unit landing cost of the commodity was deflated by the corresponding consumer price index for food;

$N I_{t}=$ Real national income in year t obtained when the gross national income was deflated by the appropriate food price index;

$E R_{t-1}=$ External Reserves in year $\mathrm{t}-1$ deflated by the appropriate food price index;

$F P_{t-1}=$ Index of domestic food production lagged one year with 1980 as the base year;

$P L_{t}=$ Population estimate;

$X R_{t}=$ Exchange rate;

$U_{t}=$ Stochastic error term;

$i=$ Food import (rice, wheat and sugar) $1,2 \& 3$ and;

$t=$ Year of import $(1,2 \ldots \mathrm{n}) ; \mathrm{n}=30$.

The following functional forms were tried in estimating these models:

\subsubsection{Linear Model}

$$
Q F_{i t}=b_{0}+b_{1} P R_{t}+b_{2} N I_{t}+b_{3} E R_{t-1}+b_{4} F P_{t-1}+b_{5} P L_{t}+b_{6} X R_{t}+U_{t}
$$

\subsubsection{Semi-Log Model}

$$
Q F_{i t}=b_{0}+b_{1} \log P R_{t}+b_{2} \log N I_{t}+b_{3} \log E R_{t-1}+b_{4} \log F P_{t-1}+b_{5} \log P L_{t}+b_{6} \log X R_{t}+U_{t}
$$

\subsubsection{Double-Log Model}

$$
\log Q F_{i t}=b_{0}+b_{1} \log P R_{t}+b_{2} \log N I_{t}+b_{3} \log E R_{t-1}+b_{4} \log F P_{t-1}+b_{5} \log P L_{t}+b_{6} \log X R_{t}+U_{t}
$$

where:

Variables are as previously defined and,

$b_{0}=$ Intercept;

$b_{1}=$ Coefficient of the price index;

$b_{2}=$ Coefficient of the real national income; 
$b_{3}=$ Coefficient of the external reserves;

$b_{4}=$ Coefficient of the food grain production;

$b_{5}=$ Coefficient of the population estimate;

$b_{6}=$ Coefficient of the exchange rate;

$b_{0}<0 ; \mathrm{b}_{2}>0 ; \mathrm{b}_{3}>0 ; \mathrm{b}_{4}<0 ; \mathrm{b}_{5}>0 ; \mathrm{b}_{6}<0$.

\section{Results and Discussion}

\subsection{Graphical Results}

The trend of importation of food in Nigeria over a 30-year period is shown in Figure 1. As shown in the graph, the selected food (rice, wheat, sugar) lumped together as the total food import witnessed a staggering decrease and increase all through the study period. This could be adduced to the fact that each of these food commodities experienced different variations in the level of its importation. For example in 1981, the quantity of rice import was 656,791 tonnes, sugar was 730,592 tonnes and wheat was 1,115,956 tonnes, making a total of 2,503,339 tonnes. In the following year, total importation reduced to about 2,414,150 tonnes, because there was a fall in the quantity of rice and sugar been imported while wheat import increased.

This observation is expected since the level of import of each item of food is bound to be demand-driven and time bound thus the observed import figure here reflects the totality of these different food items lumped together. However, effective from the last ten years, there has been a very sharp rise in the importation of these food items most especially wheat over and above those of the past years in the country. This is probably due to the multifarious use of the products in households and industries in the country as well as the rapid increase in population necessitating more mouths to be fed.

\subsection{Regression Analysis Results}

The effects of the explanatory variables on the quantity of food import in Nigeria from 1981 to 2010 were examined using regression models as a tool. The models were tried under three basic functional forms and the linear form was eventually chosen as the lead equation. This was based on the high value of coefficient of multiple determinations $\left(\mathrm{R}^{2}\right)$ and the significance of the variables in conformity with $a$ priori expectations. The effects of each of the explanatory variables on total food import were investigated by regressing the individual explanatory variable on total food import as the dependent variable. Results obtained from the analyses as shown in Table 1 reveal that they all contributed significantly $(\mathrm{P}<0.01)$ to the observed trend in total food import in Nigeria over the 30 -year period covered by the study.

However, attempts made at finding the combined effects of all the explanatory variables taken together on total food import gave results as presented in Table 2. As shown, the regression estimates indicated that all the explanatory variables (relative price, external reserves, population estimate) except national income and domes-

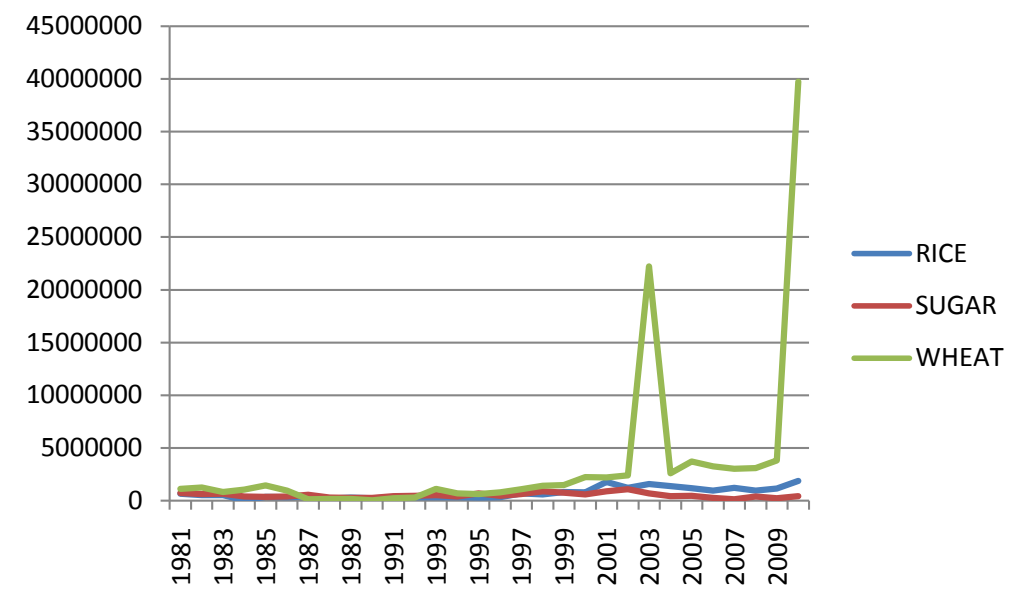

Figure 1. Trend in the quantity of selected food import (rice, wheat and sugar) of Nigeria (1981-2010). 
Table 1. Regression results of disaggregated analyses.

\begin{tabular}{cccccc}
\hline Variables & Constant & Coefficient & Standard Error & t-ratio & Significance Level \\
\hline National Income $\left(\mathrm{NI}_{\mathrm{t}}\right)$ & $2.450-\mathrm{E} 6$ & 13.371 & 3.088 & 4.331 & $\mathrm{P}<0.0001$ \\
External Reserves $\left(\mathrm{ER}_{\mathrm{t}-1}\right)$ & $2.498-\mathrm{E} 6$ & 50.429 & 11.984 & 4.208 & $\mathrm{P}<0.0001$ \\
Food Production Index $\left(\mathrm{FP}_{\mathrm{t}-1}\right)$ & $-2.305-\mathrm{E} 5$ & 46159.037 & 9367.655 & 4.927 & $\mathrm{P}<0.0001$ \\
Population Estimate $\left(\mathrm{PL}_{\mathrm{t}}\right)$ & $-2.978-\mathrm{E} 6$ & 52407.744 & 8275.533 & 6.333 & $\mathrm{P}<0.0001$ \\
Exchange Rate $\left(\mathrm{XR}_{\mathrm{t}}\right)$ & $1.680-\mathrm{E} 6$ & 24880.517 & 2751.227 & 9.043 & $\mathrm{P}<0.0001$ \\
Relative Price Index $\left(\mathrm{PR}_{\mathrm{t}}\right)$ & $2.458-\mathrm{E} 6$ & 1284.324 & 290.124 & 4.427 & $\mathrm{P}<0.0001$ \\
\hline
\end{tabular}

Source: Collated from results of several re-runs of regression analyses.

Table 2. Regression estimate of the explanatory variables on the quantity of food import.

\begin{tabular}{ccccc}
\hline Variables & Parameters & Linear & Semi-log & Double-log \\
\hline Constant & $\mathrm{b}_{\mathrm{r}}$ & $-934120.567(4.203 \mathrm{E} 6)$ & $-2.624 \mathrm{E} 7(2.367 \mathrm{E} 7)$ & $-1.428(5.106)$ \\
$\mathrm{PR}_{\mathrm{t}}$ & $\mathrm{b}_{1}$ & $724.450(1557.778)$ & $776381.8869(5122.241)$ & $0.191(0.111)$ \\
$\mathrm{NI}_{\mathrm{t}}$ & $\mathrm{b}_{2}$ & $-10.946(15.315)$ & $-1.163 \mathrm{E} 6(716675.485)$ & $-0.288(0.155)$ \\
$\mathrm{ER}_{\mathrm{t}-1}$ & $\mathrm{~b}_{3}$ & $12.410(24.318)$ & $172546.484(414506.572)$ & $0.006(0.089)$ \\
$\mathrm{FP}_{\mathrm{t}-1}$ & $\mathrm{~b}_{4}$ & $-55855.202(50645.504)$ & $-1.563 \mathrm{E} 7(5.650 \mathrm{E} 6)$ & $-2.253(1.219)$ \\
$\mathrm{PL}_{\mathrm{t}}$ & $\mathrm{b}_{5}$ & $57342.301(69793.030)$ & $2.848 \mathrm{E} 7(1.395 \mathrm{E} 7)$ & $6.146(3.009)$ \\
$\mathrm{XR}_{\mathrm{t}}$ & $\mathrm{b}_{6}$ & $29364.523(8139.977)$ & $1.438 \mathrm{E} 6(1.343 \mathrm{E} 6)$ & $0.032(0.290)$ \\
$\mathrm{R}^{2}$ & & 0.770 & 0.712 & 0.575 \\
Adjusted R & & 0.710 & 0.637 & 0.464 \\
F-ratio & & 12.839 & 9.465 & 5.1888 \\
\hline
\end{tabular}

Source: Computed from Survey Data 2013.

tic food production were positively related to food import. The coefficient of multiple determinations $\left(\mathrm{R}^{2}\right)$ of 0.77 indicates that $77.0 \%$ of the variation in the quantity of Nigeria's food import was greatly influenced by the explanatory variables included in the model. The positive signs of the coefficients indicate that, as the values or rates of those explanatory variables increase, the volume or the quantity of food import also increases.

\subsection{Correlation Analysis Results}

Table 3 shows the result of correlation analysis and explains the relationship that exists between the quantity of food import and the explanatory variables. The result is in line with a priori expectation; except that of domestic food production. It could be observed that all the variables are positively correlated $(\mathrm{P}<0.01)$ with the quantities of food imports. National income, for example observed to be positively correlated with food imports implied that the level of national income and the volume of food imports move in the same direction. All things being equal, that of external reserves and domestic food production implies that the higher the level of foreign reserves and domestic food production, the greater the volume of food imports. A fairly moderate relationship exists between volume of food imports, national income, external reserves and domestic food production.

With respect to populations and exchange rates with the trading partner, mostly United States of America, the quantity of the food imports is strongly correlated. This strong relationship implies that, population and exchange rate are very important determinants of food imports in Nigeria. The moderate positive correlation that exists between the quantity of food import and the index of domestic food production implies that, ceteris paribus, an increase in domestic food production caused a rise in the volume of food imports. This is contrary to expectation since one would have expected that an increase in domestic food production should cause a decrease in 
Table 3. The correlation matrix for food imports.

\begin{tabular}{|c|c|c|c|c|c|c|c|}
\hline & $\mathrm{QF}_{\mathrm{t}}$ & $\mathrm{PR}_{\mathrm{t}}$ & $\mathrm{NI}_{\mathrm{t}}$ & $\mathrm{ER}_{\mathrm{t}-1}$ & $\mathrm{FP}_{\mathrm{t}-1}$ & $\mathrm{PL}_{\mathrm{t}}$ & $\mathrm{XR}_{\mathrm{t}}$ \\
\hline $\mathrm{QF}_{\mathrm{t}}$ & 1 & & & & & & \\
\hline $\mathrm{PR}_{\mathrm{t}}$ & $0.642^{* *}$ & 1 & & & & & \\
\hline $\mathrm{NI}_{\mathrm{t}}$ & $0.633^{* *}$ & $0.990^{* *}$ & 1 & & & & \\
\hline $\mathrm{ER}_{\mathrm{t}-1}$ & $0.622^{* *}$ & $0.939^{* *}$ & $0.925^{* *}$ & 1 & & & \\
\hline $\mathrm{FP}_{\mathrm{t}-1}$ & $0.681^{* *}$ & $0.529^{* *}$ & $0.544^{* *}$ & $0.519^{* *}$ & 1 & & \\
\hline$P L_{t}$ & $0.767^{* *}$ & $0.741^{* *}$ & $0.752^{* *}$ & $0.721^{* *}$ & $0.954^{* *}$ & 1 & \\
\hline $\mathrm{XR}_{\mathrm{t}}$ & $0.863^{* *}$ & $0.737^{* *}$ & $0.739^{* *}$ & $0.724^{* *}$ & $0.859^{* *}$ & $0.929^{* *}$ & 1 \\
\hline
\end{tabular}

${ }^{* *}$ Correlation is significant at the 0.01 level (2-tailed); Source: Computed from Survey Data 2013.

the volume of food imports; the truth lies in the fact that based on experience the increase in domestic food production in the country could not keep pace with the increasing population, the latter outweighing the former.

\section{Findings, Conclusion and Recommendations}

\subsection{Findings}

This study was carried out to quantitatively analyse and review the trend of food imports in Nigeria between 1981 and 2010, with a view to considering factors that are believed to be responsible for the observed expansion in food import between the study periods. It was observed that the selected foods (rice, wheat, sugar) lumped together as the total food import value witnessed a staggering and differential decrease and increase all through the study period. This could be adduced to the fact that the food commodities lumped together experienced different variations in the level of importation. For example in 1981, the quantity of rice import was 656,791 tonnes, sugar was 730,592 tonnes and wheat was 115,956 tonnes, making a total of 2,503,339 tonnes. In the following year, total importation reduced to about 2,414,150 tonnes, because there was a fall in the quantity of rice and sugar been imported while wheat import increased. The correlation matrix indicates that, positive relationships exist between the quantity of food imports and all the quantifiable factor variables of national income, external reserves, population estimate, relative price and price index.

From the ANOVA results, all the variables used in assessing the variations in the quantity of food import reject the null hypothesis and therefore conclude that there is significant effect of the variables on the quantity of food imports of Nigeria.

\subsection{Conclusion}

This study concludes that all the trends investigated under study were on the increase both positively or otherwise. Thus, over the years, quantity of food import, national income, foreign reserves, population estimate, domestic food production and prices of those food imports have continued to increase. Little or no success has been achieved by the various governments to curb the increase in import and other critical factors such as population and food prices in spite of all efforts. Substantive achievements in these areas are however necessary in order to curb the decrease being experienced in the country's national income and foreign reserves.

The explanatory variables; real national income $\left(\mathrm{NI}_{t}\right)$, external reserves( $\left.\mathrm{ER}_{\mathrm{t}-1}\right)$, population estimate $\left(\mathrm{PL}_{\mathrm{t}}\right)$, Nigeria-US dollar exchange rate $\left(\mathrm{XR}_{\mathrm{t}}\right)$ and food production index $\left(\mathrm{FP}_{\mathrm{t}-1}\right)$ were all found statistically significant $(\mathrm{P}$ $<0.01)$ in explaining the variability in the quantity of food import when considered individually. The overall fit of the model indicates that, there exists a strong positive relationship between the dependent variable, food import $\left(Q_{f}\right)$, and the explanatory variables. This implies that they all tend to move towards the same direction hence in order to control the quantity of food being imported into Nigeria, all the explanatory variables need to be appropriately controlled.

The challenge for policy makers in Nigeria and other African countries is how to achieve an overall balance between the social benefits and costs in such a way that they come out better off and without compromising the principles of sustainability. Despite the significance and potentials of the agricultural sector in the past years to 
come in the Nigeria economy and, the enormous basic natural resources endowment, Nigeria's agricultural policies have not been able to move the agricultural sector to desired levels. Nigerians are still not able to feed themselves and use agriculture as a means of increasing the foreign exchange earnings, supply the industries with raw materials and create jobs for the jobless youths whose number is soaring by the day. Several constraints militating against agriculture in Nigeria have not made the local production to meet up with the increasing pace of population; these include failure of governments in their direct participation in food production, unstable political climate for foreign investment in Nigerian agriculture, increasing population, unstable prices of agricultural product and utter neglect of smallholder farmers who are the main producers of agricultural products in policy decision making.

\subsection{Policy Recommendations}

The heavy over-dependence of the country on crude-oil exports has unprecedentedly "exposed the economy to the bloom-and-bust cycles and the concomitant unstable and unpredictable volume of revenue receivable by the government" [18]. There is therefore a need for Nigeria to move away from the ideology of nationalist orientation as well as afro-centric point of view and towards unrestrained export-led growth that seeks to develop that market as the first option with corresponding development in international trade.

In the light of the above, the following recommendations could be suggested:

1). The country should maintain a healthy investment climate that can be cashed on by foreign investors, pursue efficient and effective management of the country's resources so as to raise the people's standard of living and overall economic development of the nation especially in the agricultural sector.

2). There is a need for the country to diversify the economy and focus on non-oil sector, particularly in agriculture as a long term solution to problems of food insecurity in Nigeria. Population control measures need to be put in place since rapid rate of population increase is observed to be a significant factor that makes Nigeria import more food to boost domestic production in meeting the food need of its citizenry.

On the supply side, farmers could be encouraged to go into large scale farming through the assistance of the government in form of giving guaranteed price incentives and subsidies. These will go a long way in boosting agriculture productivity.

3). Since the agriculture sector is the largest non-oil contributor to GDP, it should receive more funding from the state budgetary allocation. The present funding of about $\$ 81.41$ billion representing less than $10 \%$ of the total budget is by far not enough [19]. The foreign reserves that are said to be kept for other purposes abroad, and, at the end of the day are not well accounted for, should be used in promoting agriculture instead of storing them up idle.

4). A short term measure appears to be in policy instruments affecting commodity prices. The food imports studied in our analysis shows that the unit prices are a significant determinant too. Thus, levying a purchase tax on the consumption of imported food items or directly raising their prices will have a discouraging effect on their consumption. In the alternative, however, the government may place these items on license as to regulate the amount that is imported into the country.

\section{Acknowledgments}

The authors are grateful to all the Federal Government Agencies and Parastatals for granting them access to the Data Files and official documents. The effort of Professor E. A. Aderinola (Professor of Agricultural Economics and Farm Management), Federal University of Technology, Akure, in guiding us through the initial collation and processing of data is appreciated.

\section{References}

[1] CIA (2008) CIA — World Factbook http://www.cia.gov/library/publications/the-worldfactbook/print/ni.html

[2] Food and Agricultural Organization Statistics Division (FAOSTAT): Average Annual Growth Rates of Food and Population of Nigeria, 1990-2003; 2005.

[3] Federal Office of Statistics (FOS): National Population Commission (2006), US Library of Congress, World Bank, 1990 .

[4] Ninsin, K.A. (2000) Globalization and the Future of Africa. AAPS Occasional Paper Series, 4, 72-85. 
[5] Egwaikhide, O.E. (2000) Determinants of Imports in Nigeria: A Dynamic Specification. African Economic Research Consortium (AERC), Nairobi, Kenya 2000 Publication, Research Paper 91, 26-33.

[6] Adegboye, R.O. (2004) Land, Agricultural and Food Security in Nigeria, 3rd Faculty Lecture, Faculty of Agriculture, University of Ilorin, 105-115.

[7] Afolabi, K. (2011) Impact of Oil Export on Economic Growth in Nigeria from 1970-2006. http://abdulhamidmustapha.wordpress.com/2011/12/29/

[8] Arthur, E.D. (2009) Food Security Intiatives in Nigeria: Prospects and Challenges. Sustainable Development in Africa, 11, 186-200.

[9] Aderinola, E.A. (2008) Revolutionizing Food Production in Nigeria, Inaugural Lecture Series 50, Delivered at the Federal University of Technology, Akure, 16 September 2008, 10-11.

[10] Department for International Development (DFID) 2001 Paper Series. www.dfid. gov.uk

[11] Central Bank of Nigeria (2004) Major Economic, Financial and Banking Indicators, Research Department. http://www.cenbank.org

[12] Central Bank of Nigeria (2004) Economic Report of Regional Research and Statistics Units. 3, 1-26. http://www.cenbank.org

[13] Central Bank of Nigeria (1998) Annual Report and Statement of Account. http://www.cenbank.org

[14] Central Bank of Nigeria (2005) Statistical Bulletin, Vol. 16, December 2005. http://www.cenbank.org

[15] Central Bank of Nigeria (2007) Statistical Bulletin, Vol. 14, CBN Press, Lagos. http://www.cenbank.org

[16] Central Bank of Nigeria. Statistical Bulletin-Annual Report and Statement of Account for the Year Ended 2009. 79100. http://www.cenbank.org

[17] Food and Agricultural Organization (FAO). http://www.unnigeria.org/unagencies/fao.html

[18] Yaqub, N. (2003) Review of the 2000/2001, National Human Development Report. The Nigeria Social Scientist, 6, 35-42.

[19] Alegieno, J. (2010) Financing Agricultural Term Investment, Agricultural Finance Revisited. Economic and Financial Review, C B N Publications, No. 7, 6. 
Scientific Research Publishing (SCIRP) is one of the largest Open Access journal publishers. It is currently publishing more than 200 open access, online, peer-reviewed journals covering a wide range of academic disciplines. SCIRP serves the worldwide academic communities and contributes to the progress and application of science with its publication.

Other selected journals from SCIRP are listed as below. Submit your manuscript to us via either submit@scirp.org or Online Submission Portal.
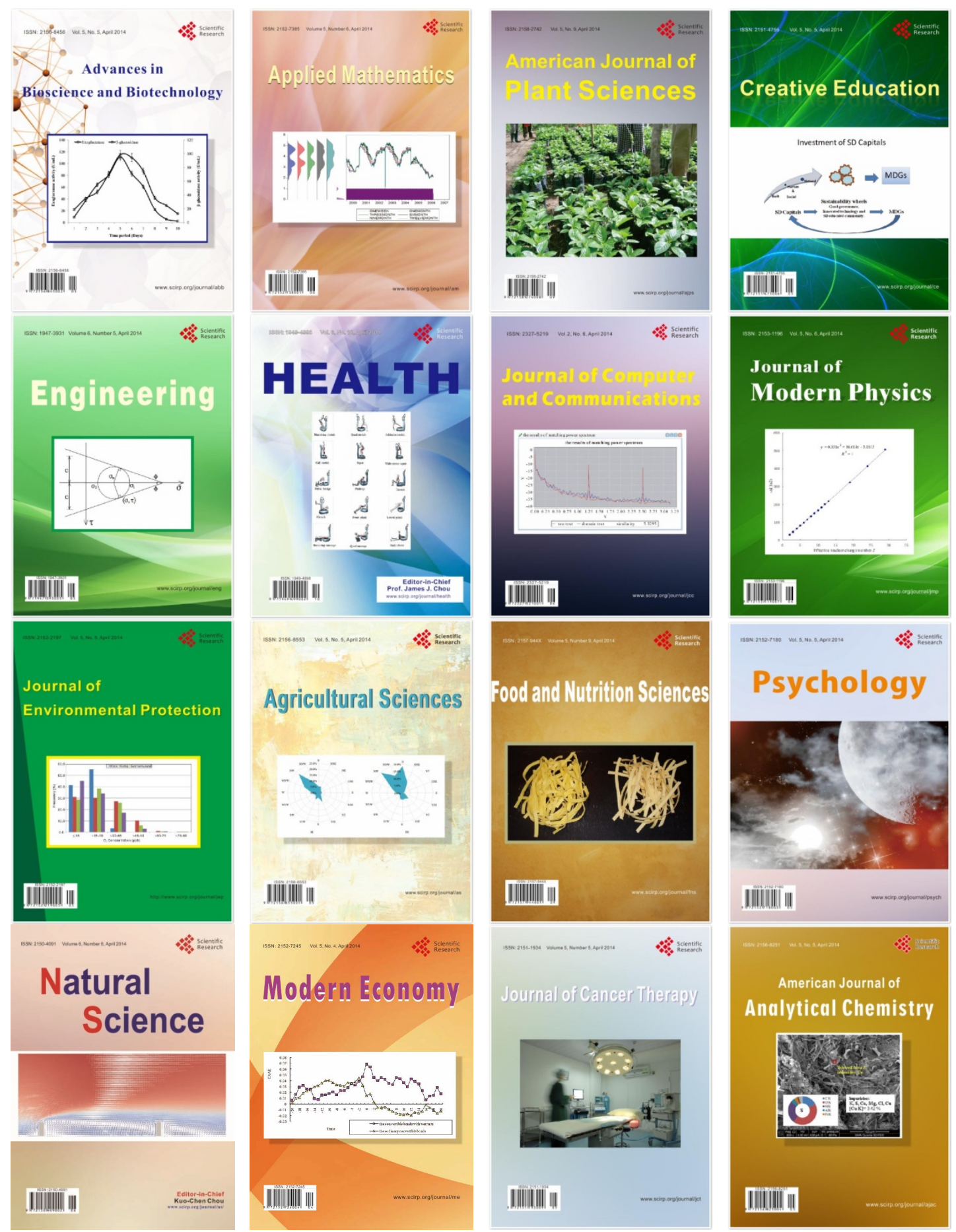